\title{
FINANCIAL AND NON-FINANCIAL CONFLICTS OF INTERESTS IN PSYCHIATRY
}

\begin{abstract}
Mario Maj*
Abstract: A conflict of interests occurs when a doctor is unduly influenced by a secondary interest (i.e., a personal incentive) in his acts concerning one of the primary interests to which he is professionally committed (the welfare of patients, the progress of science or the education of students or residents). One specific variety of conflicts of interests has monopolized the attention of the scientific and lay press: the financial conflicts of interests arising from the relationships between doctors and drug companies. A large literature has described the many, sometimes subtle, ways by which a psychiatrist can be influenced in his prescribing habits or research activities by his relationships with the industry. Some empirical evidence is now available in this area. On the other hand, it has been pointed out that the current debate on this issue is sometimes "affectively charged", or fails to take into account that the interests of patients, families and mental health professionals and those of the industry may be often convergent. Other types of conflicts of interests are beginning now to be discussed. There is evidence that the allegiance of a researcher to a given school of thought may influence the results of studies comparing different psychotherapeutic techniques, thus colliding with the primary interest represented by the progress of science. Political commitment is also emerging as a source of conflicts of interests. Financial and non-financial conflicts of interests are widespread in psychiatric practice and research. They cannot be eradicated, but must be managed more effectively than is currently the case.
\end{abstract}

Key words: conflicts of interests, pharmaceutical industry, publication bias, disclosure, allegiance effect, political commitment

\section{CONFLICTOS DE INTERESES FINANCIEROS Y NO FINANCIEROS EN PSIQUIATRÍA}

\begin{abstract}
Resumen: Se produce un conflicto de intereses cuando un médico se siente indebidamente influenciado por un interés secundario (i.e., un incentivo personal) en relación con sus deberes primarios con los cuales está comprometido profesionalmente (el bienestar de los pacientes, el progreso de la ciencia o la educación de los estudiantes o residentes). Una variedad específica de conflictos de intereses ha monopolizado la atención de la prensa científica así como de la no especializada: los conflictos de intereses financieros que surgen de la relación entre médicos y compañías farmacéuticas. Una extensa literatura ha descrito las variadas maneras, a veces sutiles, por medio de las cuales un psiquiatra puede ser influenciado por sus relaciones con la industria al aconsejar hábitos, o en sus actividades de investigación. Hoy en día se puede obtener algo de evidencia empírica en esta área. Por otra parte, se ha señalado que, a veces, el actual debate sobre esta materia se ve "cargado afectivamente" o falla en considerar que los intereses de los pacientes, de sus familias y de los profesionales de la salud mental y los de la industria podrían converger. Actualmente, se está empezando a discutir acerca de otros conflictos de intereses. Existe evidencia de que la cercanía de un investigador a alguna línea de pensamiento puede influenciar los resultados de estudios al comparar diferentes técnicas psicoterapéuticas, chocando, por tanto, con el interés primario representado por el progreso de la ciencia. El compromiso político también está emergiendo como fuente de conflictos de intereses. Conflictos de intereses financieros y no financieros están muy esparcidos en la práctica y la investigación psiquiátricas. No pueden ser erradicados, pero deben ser tratados con mayor eficacia de la que se observa hoy en día.
\end{abstract}

Palabras clave: conflictos de intereses, industria farmacéutica, sesgo de la publicación, desvelar, efecto de lealtad, compromiso político

\section{CONFLITOS DE INTERESSES FINANCEIROS E NÁO FINANCEIROS EM PSIQUIATRIA}

Resumo: Ocorre conflito de interesses quando um médico se sente indevidamente influenciado por um interesse secundário (i.e., um incentivo pessoal) em relação aos seus deveres primários, com os quais está comprometido profissionalmente (o bem-estar dos pacientes, o progresso da ciência, a educaçáo dos estudantes ou residentes). Uma variedade específica de conflitos de interesses tem monopolizado a atenção da literatura científica, assim como da não especializada: os conflitos de interesses financeiros que surgem da relação entre médicos e companhias farmacêuticas. Uma extensa literatura tem descrito as variadas maneiras, às vezes sutis, nas quais um psiquiatra pode ser influenciado devido às suas relaçóes com a indústria ao aconselhar hábitos, ou em suas atividades de pesquisa. Hoje em dia, pode-se obter alguma evidência empírica nesta área. Por outra parte, tem-se assinalado que, às vezes, o atual debate sobre esta matéria se vê "carregado afetivamente" ou falha ao considerar que os interesses dos pacientes, de suas famílias, dos profissionais da saúde mental e os da indústria poderiam convergir. Atualmente, está se iniciando a discussão sobre outros conflitos de interesses. Existe evidência de que a proximidade de um pesquisador com alguma linha de pensamento pode influenciar os resultados de estudos ao comparar diferentes técnicas psicoterapêuticas, conflitando, portanto, com o interesse primário representado pelo progresso da ciência. O compromisso político também está emergindo como fonte de conflitos de interesses. Conflitos de interesses financeiros e não financeiros estáo muito difundidos na prática e na pesquisa psiquiátricas. Não podem ser erradicados, porém devem ser tratados com maior eficácia em relação ao que se observa hoje em dia.

Palavras-chave: conflitos de interesses, indústria farmacêutica, obliquidade da publicação, cuidar, efeito de lealdade, compromisso político

\footnotetext{
Department of Psychiatry, University of Naples SUN, Naples. Italy
}

Correspondence: majmario@tin.it 
A conflict of interests occurs when a doctor is unduly influenced by a secondary interest (i.e., by a personal incentive) in his acts concerning one of the primary interests to which he is professionally committed $(1-3)$.

The primary interests to which a doctor is professionally committed are: first of all, the welfare of his patients; then, if he is a researcher, the progress of science; and, if he is a scholar, the education of his students, residents or colleagues(1-3).

A conflict may also arise between two of these primary interests. For instance, between the welfare of an individual patient and the progress of science. This conflict has been covered in the literature, and usually referred to as the "clinician-scientist dilemma". The expression "conflict of interests" is not used in this case. Furthermore, a doctor may have other professional roles in addition to those of clinician, scientist and scholar. For instance, he may act as a consultant to the judiciary system or to the government. This may be a source of conflicts. This issue has been covered in the literature concerning the practice of forensic psychiatry, where there is often a potential conflict between the welfare of individual patients and the mandate the psychiatrist receives from the court(4). This conflict, however, is rarely referred to as a conflict of interests. The expression "dual commitment" or "dual loyalty" conflict is more frequently used.

The expression "conflict of interests" is commonly used, instead, when a conflict arises between one of the above-mentioned primary interests to which a doctor is professionally committed and one of several possible secondary interests (i.e. personal incentives). These secondary interests include: a) the motivation to obtain a financial gain for oneself or an institution (such as a hospital or a university department); b) the motivation to obtain personal recognition, career advancement or visibility in the media (the so-called academic currency); c) the motivation to favour a relative, a friend or a colleague; d) the allegiance to a school of thought, a socio-political position or a religious belief(1-3).

Having a potential conflict of interests, i.e., one which is seen as possibility, is different from having an actual conflict of interests, i.e., one documented as a fact. A common misunderstanding is that having a potential conflict of interest means that the individual is necessarily doing something wrong or unethical. On the contrary, judging that a potential conflict of interests exists in a given situation means that the situation is such that any well-intentioned person might be subtly influenced(5).

Also, a potential conflict of interests may be more or less substantial. Being a regular consultant or in the board of directors of a drug company is not the same thing as eating a pizza at an industry-sponsored lunch(6).

It is also important to clarify that a conflict of interests may or not be perceived as such by the involved person. Actually, it is common for people to believe that they are invulnerable to influences to which they believe others are susceptible(7).

\section{Financial conflicts of interests arising from relationships to drug companies}

Of the universe of conflicts of interests which may occur in medical (and psychiatric) research and practice, one specific variety has monopolized the attention of the scientific and lay press: the financial conflicts of interests arising from the relationships between physicians and drug companies. Much has been said and much has been written on this issue. Let us focus on the points which are currently supported by some empirical evidence.

It is to some extent documented that accepting funds for travel and accommodation on the occasion of sponsored symposia is associated with an increased prescription of the sponsor's medications, and that physicians who use to request the addition of drugs to their hospital formulary are more likely to have accepted money from drug companies(8).

It is also documented that studies sponsored by the industry are more likely to report outcomes favourable to the sponsor's product(9). A systematic review(10) found that in $90 \%$ of head-to-head comparison studies of second-generation antipsychotics the reported overall outcome was in favour of the sponsor's drug. Another study(11) reported that authors' conflict of interests was significantly associated with positive trial outcomes in industry-supported clinical trials in psychiatry.

Since almost all trials of new medications in the psychiatric field are now funded by a drug company, the suspicion is warranted that recent research evidence in the field of psychopharmacotherapy is to some extent biased. 
The sources of bias in the design, conduct and data analysis include(12): a) using a dose of the comparison drug which is outside its standard clinical range; b) altering the usual dosing schedule of that comparison drug; c) using self-serving assessment instruments; d) using misleading statistical analyses; e) picking favourable endpoints and outcome measures a posteriori. The sources of bias in the report of the results of trials include (12): a) selectively emphasizing findings which are favourable to the sponsored drug; b) masking unfavourable side effects of that drug; c) repeatedly publishing the same data in papers with a different first author (so that even meta-analyses and systematic reviews may be misled); d) publishing data in sponsored supplements where papers are not peer-reviewed; e) withholding unfavourable results.

In addition to this, it has been claimed that eminent researchers with significant financial conflicts of interests may exercise their impact on the field also in their role of referees or editors of scientific journals, thus creating what have been called "special interest groups"(13).

The same experts are also the most likely to contribute to the production of clinical guidelines. In fact, a further well-documented evidence is that most authors of clinical practice guidelines have financial relationships with companies whose drugs are considered in those guidelines. A study showed that $59 \%$ of contributors to clinical guidelines had received financial support from the industry. Only 7\% of them thought that their relationship with drug companies had influenced their own recommendations, whereas the percentage of those who thought that their co-authors' recommendations had been influenced was three times higher(14).

A further point which is now to some extent documented is that industry-sponsored CME activities are often biased in favour of the sponsor's products, and that physicians attending those activities tend to prescribe those products more often than competing drugs (15). In several countries, there are now so-called medical education and communication agencies, paid by drug companies, which put together the programme of sponsored CME events, select and pay the speakers, and sometimes prepare the speakers' slides(16). These agencies are very clear in explaining the purpose of their business to drug companies. These are some quotes from their advertisements: "Medical education is a powerful tool that can deliver your message to key audiences and get those audiences to take action that benefits your product"; "Putting the science of medicine to work for you. Preparing and building the market through professional education"(16).

The main antidote to this situation that our profession has been able to develop is disclosure (i.e., the disclosure of potential financial conflicts of interests by researchers authoring a scientific paper, contributing to the production of clinical guidelines, or presenting at a scientific meeting or a CME course). The idea is that, since eradicating or even limiting financial conflicts of interests is unfeasible, at least the readership of scientific journals and the audience of scientific meetings should be aware of their existence and of the possibility that the evidence presented be consequently biased. However, this antidote has not been very effective up to now. In fact, while self-reports reveal that more than $33 \%$ of senior journal authors have financial ties to funders of research, the rate of self-disclosure in journals has been reported to be less than $2 \%(17)$.

The International Committee of Medical Journal Editors has recently produced "Uniform requirements for manuscripts submitted to biomedical journals", stating that "when authors submit a manuscript, whether an article or a letter, they are responsible for disclosing all financial and personal relationships that might bias their work" (18).

The crucial point, however, is what happens if somebody refuses or fails to disclose a relationship with industry. The consequences of this refusal or failure should be substantial enough to ensure the effectiveness of the policy(19). Indeed, some professional associations have issued statements according to which failure to disclose a financial conflict of interests may constitute grounds for disciplinary action(20). However, professional associations are usually too remote to be effective, and it should be the responsibility of local institutions to establish a peer review committee which is really functioning and deals with these issues(19). On the other hand, concerns have been also raised about common conflicts of interests of members of institutional review boards, who may be inappropriately critic of other colleagues due to jealousy over their achievements or different school orientations(21).

Concerning the issue of publication bias, a possible antidote which has been frequently proposed is the creation of a registry in which all new trials are re- 
corded when they start. This idea has been recently implemented by the World Health Organization, which has launched an International Clinical Trials Registry Platform, urging research institutions and companies to register all medical studies that test treatments on patients or healthy volunteers(22). The issue of publication policies has been also addressed in a set of good publication guidelines for pharmaceutical industry, produced by a working group including several companies, although a final disclaimer specifies that the guidelines may not necessarily represent the policies of those companies(23).

\section{Has the issue of financial conflicts of interests been overemphasized in psychiatry?}

Four main arguments have been put forward by those who believe that the issue of financial conflicts of interests arising from the relationships between psychiatrists and drug companies has been overemphasized in the field of psychiatry.

The first argument is that the current debate on financial conflicts of interests in the psychiatric field is sometimes biased by ideological prejudice: "The debate on this issue may have become so vitriolic in psychiatry because it taps into a more profound disagreement about the role of drugs in psychiatry"(24). A more general critique of capitalism may also be involved: "Is the making of money on the back of drug development and sales somehow immoral?"(24). Moreover, an oppositional attitude towards drug companies may carry professional benefits, including a priority when public money is distributed for research(25). This argument is certainly an interesting one. However, it should not be brought so far as to deny the impact of financial conflicts of interests on the psychiatric field, especially since this impact is now well documented by research evidence.

The second argument is that the current focus on financial conflicts of interests arising from the relationships between psychiatrists and drug companies sometimes fails to take into account the fact that the pharmaceutical industry is today virtually the only source of development of new medications in our field, and that we, our patients and their families do need new, more effective, better tolerated and more targeted medications. To a large extent, therefore, our interests, those of patients and their families and those of the industry may be regarded as convergent (26-28). However, this is not necessarily true, if the new drugs which are promoted are more expensive and do not really bring significant advantages with respect to the old ones. Furthermore, the fact that we are necessarily partners does not mean that this partnership should not have clear rules, better if agreed upon by both parties involved.

The third argument is that drug companies are today, in many countries, the only accessible source of financial support for drug trials, the organization of large scientific meetings and CME events, so that it is practically unavoidable for a professional who wants to implement one of those activities to look for the support of the industry. This is most probably true. However, again, the fact that a partnership is unavoidable does not imply that such a partnership should not have rules.

The fourth argument is that the relationship with drug companies is not the only source of financial conflicts of interests for physicians and researchers, although it is by large the most visible. This is certainly a good point. There are indeed financial conflicts of interests in psychiatric practice and research which do not involve the pharmaceutical industry. For instance, public health sponsors usually have an interest to avoid spending money on the most expensive drugs(25). This may affect the conduct and the outcome of the studies they fund (e.g., comparisons between old- and new-generation drugs), especially if the report of results in line with the public sponsor's interest involves a better chance for researchers to be funded again by that sponsor.

Another almost unexplored issue is that of financial conflicts of interests related to the practice of managed care(29). Many physicians are currently pressured by their administrations to be more "productive" (i.e., to see more patients during working hours) and to use the least expensive interventions. This increased productivity and use of the cheapest treatments may not be in the best patients' interest. If a financial incentive is involved, which is often the case, a financial conflict of interests may be generated.

\section{Non-financial conflicts of interests in psychiatry}

Financial conflicts of interests have attracted a lot of interest in the past few decades. However, they are 
certainly not the only conflicts of interests affecting research and practice in medicine, and particularly in psychiatry.

An example of non-financial conflict of interests affecting psychiatric research is given by the possible conflict between the secondary interest represented by the researcher's allegiance to a given school of thought and the primary interest represented by the progress of science(3).

The impact of this "allegiance effect" on the outcome of psychotherapy research has been repeatedly described. A systematic review(30) found that the combination of three measures of researcher's allegiance accounted for $69 \%$ of the effect size of treatment outcome in studies comparing three psychotherapeutic techniques. Interestingly, some mechanisms by which the researcher's allegiance may operate are very similar to those explaining the impact of financial conflicts of interests on the outcome of drug trials: the selection of a less effective intervention to compare with the researcher's favoured treatment; the unskilful use of the comparison treatment; a focus on data favouring the preferred treatment in study reports; and the failure to publish negative data.

The impact of this allegiance effect (along with the fact that the proponents of some psychotherapies may for various reasons be less interested in the scientific validation of their techniques) may bias the research evidence concerning the relative efficacy of the various psychotherapies, exactly like the impact of financial conflicts of interests may bias the research evidence concerning the relative efficacy of the various psychotropic drugs. Not surprisingly, it has been argued that "the balance of investigator allegiance across the schizophrenia literature is against psychodynamic or supportive methods and in favour of CBT approaches" (31).

An example of non-financial conflict of interests affecting psychiatric practice is given by the possible conflict between the secondary interest represented by a psychiatrist's political commitment and the primary interest represented by patients' welfare(3).

In my country, a minister of education stated some years ago that a psychiatrist should always be a political activist, and, indeed, being a political activist may be very useful to a psychiatrist in fulfilling his professional duties. However, it is a fact that some political orien- tations are often associated with a strong prejudicial attitude against the use of medications in psychiatry and the hospitalization of psychiatric patients. This prejudicial attitude may sometimes amount to fanaticism ("those who prescribe psychotropic drugs are like pushers"; "psychiatry does not need any beds").

Of course, everybody is free to hold and profess even extreme ideas, and one could argue that these views may sometimes represent a stimulus to the field. However, if a psychiatrist holding such ideas (or, even worse, a psychiatrist wishing to please a head physician or a manager holding such ideas) denies pharmacological treatment and/or hospitalization to a severely depressed patient, who then commits suicide, isn't this a tragic instance of conflict between the secondary interest represented by the psychiatrist's political commitment and the primary interest represented by the patient's welfare? (3).

A prejudicial attitude against the use of medications in psychiatry may more often manifest itself as the stubborn refusal to learn to use those medications adequately, and to even consider reading drug treatment guidelines, because this would mean to acknowledge the essential therapeutic role of something which is instead regarded as an only marginal ingredient of care. The consequence of this attitude is that medications are indeed used, but in an irrational and chaotic way, again with a significant detriment to patients' welfare(3).

As I mentioned above, it has been rightly pointed out that there are now in our field "special interest groups", consisting of prominent leaders with significant financial conflicts of interests (arising from their relationships to drug companies) who exercise a powerful impact on the field in their various capacities (e.g., as editors or referees of scientific journals, or contributors to treatment guidelines)(13). One could argue, however, that similar "special interest groups" consisting of prominent leaders with significant ideological conflicts of interests may also exist. They may exercise an equally powerful impact on the field acting, for instance, as contributors to mental health policy guidelines or consultants to governments. Furthermore, another emerging circle is that of "two-sided" experts, eloquently advocating opposite positions (for instance, in favour or against the use of new-generation medications) depending on the context in which they speak (e.g., a sponsored symposium vs. a meeting of a governmental task force)(3). 


\section{Conclusion}

Conflicts of interests are widespread in medical, and psychiatric, practice and research. Financial conflicts of interests, particularly those arising from the relationships of physicians and researchers to the pharmaceutical industry, have a significant impact on the psychiatric field, now to some extent documented by research. However, non-financial conflicts of in- terests are probably both common and significant in psychiatric practice and research, although currently underemphasized and understudied.

Conflicts of interests in psychiatric research and practice cannot be eradicated, but must be managed more effectively than is currently the case, and this is certainly an area which our professional associations should be more active in the future.

\section{References}

1. Thompson DF. Understanding financial conflicts of interest. N Engl J Med 1993; 329: 573-576.

2. Maj M. Conflicts of interests in psychiatric practice and research. Psychiatrie 2005; 3: 138-140.

3. Maj M. Non-financial conflicts of interests in psychiatric research and practice (Editorial). Br J Psychiatry 2008; 193: 91-92.

4. Sen P, Gordon H, Adshead G, Irons A. Ethical dilemmas in forensic psychiatry: two illustrative cases. J Med Ethics 2007; 33: 337-341.

5. Warner TD, Gluck JP. What do we really know about conflicts of interest in biomedical research? Psychopharmacology 2003; 171: 36-46.

6. Fava GA. Financial conflicts of interest in psychiatry. World Psychiatry 2007; 6: 19-24.

7. Cialdini RB, Trost MR. Influence, social norms, conformity, and compliance. In: Gilbert DT, Fiske ST, Lindzey G, (eds.) The handbook of social psychology, 4th ed. New York: Oxford University Press, 1998.

8. Wazana A. Physicians and the pharmaceutical industry. Is a gift ever just a gift? JAMA 2000; 283: 373-380.

9. Lexchin J, Bero LA, Djulbegovic B, Clarke O. Pharmaceutical industry sponsorship and research outcome and quality: systematic review. BMJ 2003; 326: 1167-1170.

10. Heres S, Davis J, Maino K, Jetzinger E, Kissling W, Leucht S. Why olanzapine beats risperidone, risperidone beats quetiapine, and quetiapine beats olanzapine: an exploratory analysis of head-to-head comparison studies of secondgeneration antipsychotics. Am J Psychiatry 2006; 163: 185-194.

11. Perlis RG, Perlis CS, Wu Y, Hwang C, Joseph M, Nierenberg AA. Industry sponsorship and financial conflict of interest in the reporting of clinical trials in psychiatry. Am J Psychiatry 2005; 162: 1957-1960.

12. Safer DJ. Design and reporting modifications in industry-sponsored comparative psychopharmacology trials. J Nerv Ment Dis 2002; 190: 583-592.

13. Fava GA. Conflict of interest and special interest groups. Psychother Psychosom 2001; 70: 1-5.

14. Choudhry NK, Stelfox HT, Detsky AS. Relationships between authors of clinical practice guidelines and the pharmaceutical industry. JAMA 2002; 287: 612-617.

15. Relman AS. Separating continuing medical education from pharmaceutical marketing. JAMA 2001; 285: 20092012.

16. Ross JS, Lurie P, Wolfe SM. Medical education services suppliers: a threat to physician education. Washington: Public Citizen's Health Research Group; 2000.

17. Hussain A, Smith R. Declaring financial competing interests: survey of five general medical journals. BMJ 2001; 323: 263-264.

18. International Committee of Medical Journals Editors. Uniform requirements for manuscripts submitted to biomedical journals: writing and editing for biomedical publication. Available at www.icmje.org/index.html.

19. Foster RS. Conflicts of interest: recognition, disclosure, and management. J Am Coll Surg 2003; 196: 505-517.

20. American College of Surgeons. Statements on principles, 1987. Available at www.org/fellows_info/statements/stonprin. html.

21. Francis L. IRBs and conflicts of interest. In: Spece RG, Shimm DS, Buchanan AE, (eds.) Conflicts of interest in clinical practice and research. New York: Oxford University Press, 1996.

22. World Health Organization. International clinical trials registry platform. Geneva: World Health Organization; 2006. 
23. Wager E, Field EA, Grossman L. Good publication practice for pharmaceutical companies. Curr Med Res Opin 2003; 19: 149-154.

24. Goodwin G. Conflicting interests and doing right. World Psychiatry 2007; 6: 25-26.

25. Vieta E. Psychiatry: from interest in conflicts to conflicts of interest. World Psychiatry 2007; 6: 27-29.

26. Thase ME. On the property of collaborations between academicians and the pharmaceutical industry: an alternate viewpoint. World Psychiatry 2007; 6: 29-31.

27. Paul SM, Tohen M. Conflicts of interests and the credibility of psychiatric research. World Psychiatry 2007; 6: 33-34.

28. Nierenberg AA. A counter proposal to manage financial conflicts of interests in academic psychiatry. World Psychiatry 2007; 6: 34-36.

29. Rodwin MA. Medicine, money, and morals: physicians' conflicts of interest. New York: Oxford University Press; 1993.

30. Luborsky L, Diguer L, Seligman DA, Rosenthal R, Krause ED, Johnson S, Halperin G, Bishop M, Berman JS, Schweizer E. The researcher's own therapy allegiance: a "wild card" in comparisons of treatment efficacy. Clin Psychol: Sci Pract 1999; 6: 95-106.

31. Paley G, Shapiro DA. Lessons from psychotherapy research for psychological interventions for people with schizophrenia. Psychology and Psychotherapy: Theory, Research and Practice 2002; 75: 5-17.

Recibido: 3 de julio de 2009

Aceptado: 28 de julio de 2009 